\title{
Phytoplankton and Eutrophication Degree Assessment of Baiyangdian Lake Wetland, China
}

\author{
Xing Wang, ${ }^{1,2}$ Yu Wang, ${ }^{1,2}$ Lusan Liu,, ${ }^{1,2}$ Jianmin Shu, ${ }^{1}$ Yanzhong Zhu, ${ }^{1,2}$ and Juan Zhou ${ }^{1,2}$ \\ ${ }^{1}$ State Key Laboratory of Environmental Criteria and Risk Assessment, Chinese Research Academy of Environmental Sciences, \\ Beijing 100012, China \\ ${ }^{2}$ State Environmental Protection Key Laboratory of Estuarine and Coastal Environment, Chinese Research Academy of Environmental \\ Sciences, Beijing 100012, China
}

Correspondence should be addressed to Lusan Liu; liuls@craes.org.cn

Received 27 April 2013; Accepted 30 June 2013

Academic Editors: J. Bai and A. Li

Copyright (C) 2013 Xing Wang et al. This is an open access article distributed under the Creative Commons Attribution License, which permits unrestricted use, distribution, and reproduction in any medium, provided the original work is properly cited.

Eight typical sampling sites were chosen to investigate the phytoplankton community structure and to assess the eutrophication degree of Baiyangdian Lake in 2009. Our results showed that among the total 133 species identified, Cyanophyta, Chlorophyta, and Bacillariophyta dominated the phytoplankton community. In spring, Chlorophyta and Bacillariophyta were the dominant phyla, and the dominant species included Chlorella sp., Chroomonas acuta Uterm., and Microcystis incerta Lemm.; the density of the phytoplankton ranged from $496 \times 10^{4}$ to $6256 \times 10^{4}$ cells/L with an average of $2384 \times 10^{4}$ cells/L. However, Chlorophyta and Cyanophyta became the dominant phyla in summer, and the dominant species were Chlorella sp., Leptolyngbya valderiana Anagn., and Nephrocytium agardhianum Nageli.; the density of the phytoplankton varied from $318 \times 10^{4}$ to $4630 \times 10^{4}$ cells/L with an average of $1785 \times 10^{4}$ cells/L. The density of the phytoplankton has increased significantly compared to the previous investigations in 2005 . The index of Carlson nutritional status (TSIM) and the dominant genus assessment indicated that the majority of Baiyangdian Lake was in eutrophic state.

\section{Introduction}

Eutrophication is a phenomenon, in which the excess trophic substances (i.e., nitrogen and phosphorus) in lakes, reservoirs, estuaries, rivers, and certain coastal waters cause a great increase in algae and a decrease in dissolved oxygen, thus, leading to serious death of a lot of fishes and other hydrophytes. A lot of freshwater water bodies have occurred eutrophication in the 1990s [1], and it was the first time for eutrophication began to become the major pollution problem of lakes and reservoirs in most countries such as Europe and North America. An investigation showed that eutrophication took place in 54\% of Asian lakes, 53\% of European lakes, $48 \%$ of lakes in North America, $41 \%$ of lakes in South America, and even 28\% of lakes in Africa [2]. For example, Japan's second largest lake (Lake Kasumigaura) once played a very important role in irrigation, human life, industry, inland fishery, recreation, and so on; however, serious eutrophication has been observed in this lake since the early 1900, and this once well-known tourist attraction was forced to shut down due to the deteriorative water quality [3].

There are in total 2,759 lakes with the area of more than $1 \mathrm{~km}^{2}$ in China, which covers an area of $91019 \mathrm{~km}^{2}$ and makes up $0.95 \%$ of land area in China. About onethird of these lakes is fresh water lake, and they are mainly located in eastern coastal area and the lower-middle reaches of Yangtze River. In recent years, the rapid development of economy, the inappropriate development and utilization of water resources, and the worsening agriculture nonpoint pollution have resulted in serious eutrophication: most of these lakes have been plagued by eutrophication or are in the course of eutrophication development [4]; the structure and function of the lake ecosystems have degenerated with the frequent occurrence of blue-green algae blooms and pollution-induced water shortage. These water problems seriously affect the production activities and life of people in the lake region, limit the sustainable development of regional 
social economy, and cause great financial losses and social problems [5].

Phytoplankton including many species is widely distributed in the aquatic ecosystem, which maintains the structural functions of ecosystem and plays an important and irreplaceable role of indicator and purifier on lake pollution, through participating in material cycle and energy flow in lakes $[6,7]$. In recent years, the species and community structure characteristics of phytoplankton combined with the chemical detection of water quality have been generally accepted as environmental assessment indicators [8]. Among them, the index of Carlson nutritional status (TSIM) and the dominant genus assessment have been widely applied for the assessment of eutrophication in lakes and reservoirs $[9,10]$.

Baiyangdian Lake, located in the eastern part of North China Plain, is the largest fresh water lake in Haihe River Basin. It is also the largest inland shallow lake in North China and is historically given the name of "the Pearl of North China" because of its excellent water quality and great biodiversity. However, in the highly populated Baiyangdian Lake area, industrial effluents and domestic sewage flow directly into the lake through surface runoff [11], upstream water supply declines, and water level drops, which results in low self-purifying capacity of this lake. As a result, the water quality of this lake is increasingly more worse [12] with serious eutrophication [13].

The objectives of this paper were to identify the species composition and spatial distribution of the phytoplankton and to evaluate the eutrophication degree in Baiyangdian Lake.

\section{Materials and Methods}

2.1. Study Area. Baiyangdian Lake, with an area of about $366 \mathrm{~km}^{2}$, is a typical plant-dominated shallow freshwater lake consisting of about 143 lake parks, with a maximum depth of $4.0 \mathrm{~m}$. Reeds and cattails are the dominant macrophyte, covering about $22 \%$ of the lake area. Raised fields with reeds and cattails coverings are divided into multiple blocks by more than 3,700 artificial ditches. These ditches are regarded as multiple connected corridors in the reed wetland landscape. It has the semiarid monsoon climate with the average annual precipitation of $570.2 \mathrm{~mm}$, and the average annual evaporation in this region is $1369 \mathrm{~mm}$, which is far higher than the average annual precipitation [14]. Meanwhile, the reduction of lake surface area and depth worsens the eutrophic situation.

2.2. Sample Collection and Analysis. Eight sampling sites were chosen in the Baiyangdian Lake $\left(115^{\circ} 56^{\prime}\right.$ to $116^{\circ} 06^{\prime} \mathrm{E}$, $38^{\circ} 49^{\prime}$ to $38^{\circ} 57^{\prime} \mathrm{N}$; Figure 1), and phytoplankton and relevant environment factors were investigated in the early April (spring) and in the middle of June (summer) of 2009. Quantitative sample collection of phytoplankton is as follows: organic glass hydrophore was used to collect water samples; the volume of water sample was $1000 \mathrm{~mL}$; for water which was no more than 3 meters deep and the water masses of which were well mixed, one sample of $1000 \mathrm{~mL}$ needed to be collected from the surface ( 0.5 meter), while for water which was 3 to 10 meters deep, one sample of $500 \mathrm{~mL}$ from the surface and one sample of $500 \mathrm{~mL}$ from the bottom needed to be collected and mixed. Lugol's solution was used to fix samples, and $1 \%$ (vol) formalin solution was used to preserve samples. The treatment, analysis method, and water quality analysis method of the phytoplankton samples were carried out according to the standard methods from Lake Ecosystem Observation Method [15].

2.3. Data Processing. Data were proceeded using SPSS and PRIMER V6 software packages [16] to get ecological indicators such as species number, density, Shannon-Weiner index, and richness index of phytoplankton.

Shannon-Weiner index is calculated using formula (1):

$$
H^{\prime}=-\sum_{i=1}^{s} P_{i} \ln P_{i},
$$

where $P_{i}$ represents the percentage of species $i$ in the samples; for example, if the total number of species is $N$ and the number of species $i$ is $n_{i}$, then $P_{i}=n_{i} / N$.

Richness index is calculated using formula (2):

$$
d=\frac{(S-1)}{\log _{2} M},
$$

where $S$ is the number of species in the samples collected from certain sampling sites and $M$ is the number of individuals of all the species in this sampling site.

Uniformity is calculated using formula (3):

$$
J^{\prime}=\frac{H^{\prime}}{\ln S},
$$

where $H^{\prime}$ is the Shannon-Weiner index and $S$ is the number of species in the samples collected from certain sampling sites.

\section{Results and Discussion}

3.1. Community Composition and Biodiversity. All the phytoplankton collected in both dates could be categorized into 8 phyla and 133 species (genus). Amongst them, 8 phyla and 78 species (genus) were observed in spring, and Chlorophyta, Cyanophyta, and Bacillariophyta were the dominate phytoplankton community with the greatest number of Chlorophyta including 33 species (genus), which accounted for $42.3 \%$ of the total number of algae. Fifteen species (genus) of Bacillariophyta and 11 species (genus) of Cyanophyta were observed, accounting for $19.2 \%$ and $14.1 \%$ of the total number of algae, respectively. There were 7 species (genus) for Euglenophyta and 5 species (genus) for Cryptophyta, accounting for $9.0 \%$ and $6.4 \%$ of the total number of algae, respectively. However, there were only 2 species (genus) for Pyrrophyta, 2 species (genus) for Xanthophyta, and 3 species (genus) for Chrysophyta, accounting for $2.6 \%, 2.6 \%$, and $3.8 \%$ of the total number of algae, respectively, (Figure $2(\mathrm{a})$ ).

Eight phyla and 133 species (genus) were observed in summer, and Chlorophyta, Cyanophyta, and Euglenophyta 


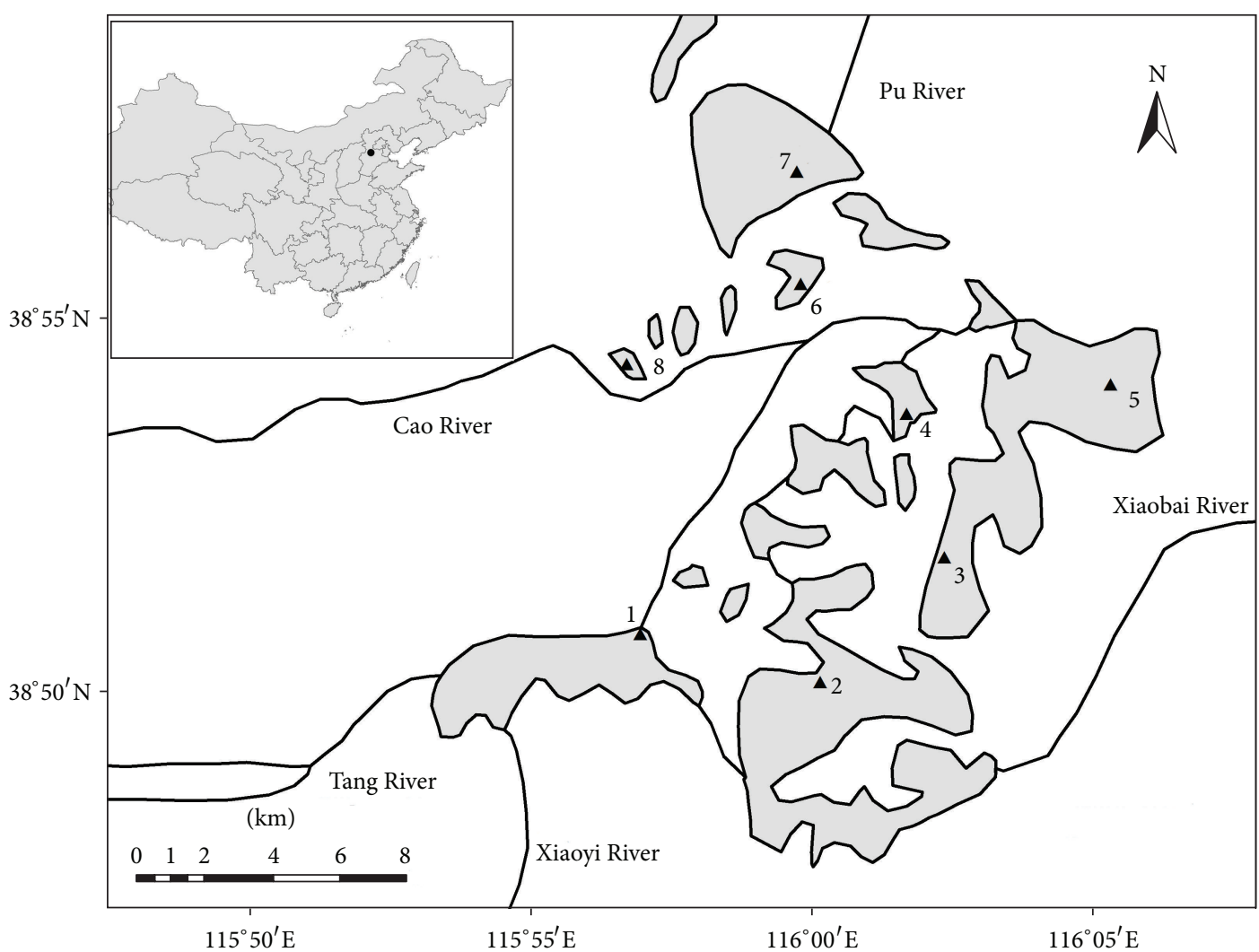

- Sample sites

Baiyangdian Lake

- River

Figure 1: Sampling sites of the Baiyangdian Lake in Hebei Province, China.

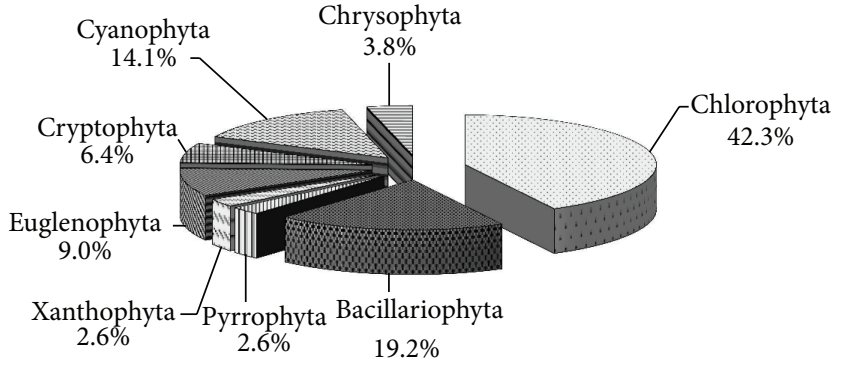

(a)

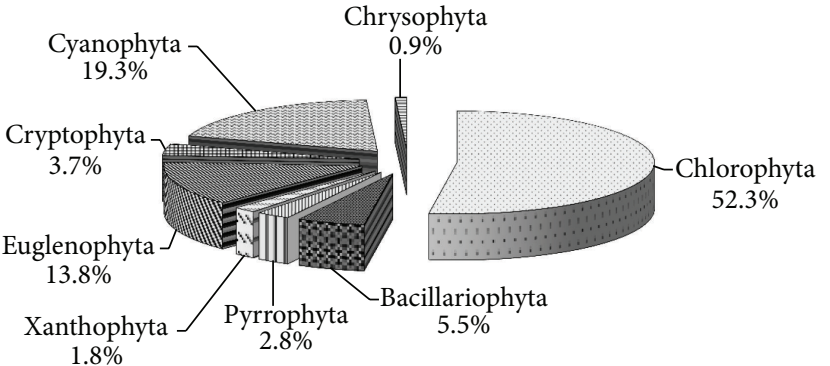

(b)

FIGURE 2: Composition percentage of the main phytoplankton in the study area in spring (a) and summer (b).

were the dominate phytoplankton community with the greatest number of Chlorophyta including 57 species (genus), which accounted for $52.3 \%$ of the total number of algae. Twenty-one species (genus) of Cyanophyta and 15 species (genus) of Euglenophyta were observed, accounting for $19.3 \%$ and $13.8 \%$ of the total number of algae, respectively. There were 6 species (genus) for Bacillariophyta and 3 species (genus) for Pyrrophyta, accounting for 5.5\% and $2.8 \%$ of the total number of algae, respectively. However, there were only 2 species (genus) for Xanthophyta, 4 species (genus) for Cryptophyta, and 1 species (genus) for Chrysophyta, accounting for $1.8 \%, 3.7 \%$, and $0.9 \%$ of the total number of algae, respectively, (Figure 2(b)). In spring, the first dominant species in Baiyangdian Lake is Chlorella sp. which belongs to the Chlorophyta phylum with the occurrence frequency of $100 \%$. The second dominant species are Chroomonas acuta Uterm. and Microcystis incerta Lemm., which belong to the Cryptophyta and Cyanophyta phyla with the occurrence frequency of $87.5 \%$ and $100 \%$, respectively. In summer, the first dominant species in Baiyangdian Lake is Chlorella sp. which 


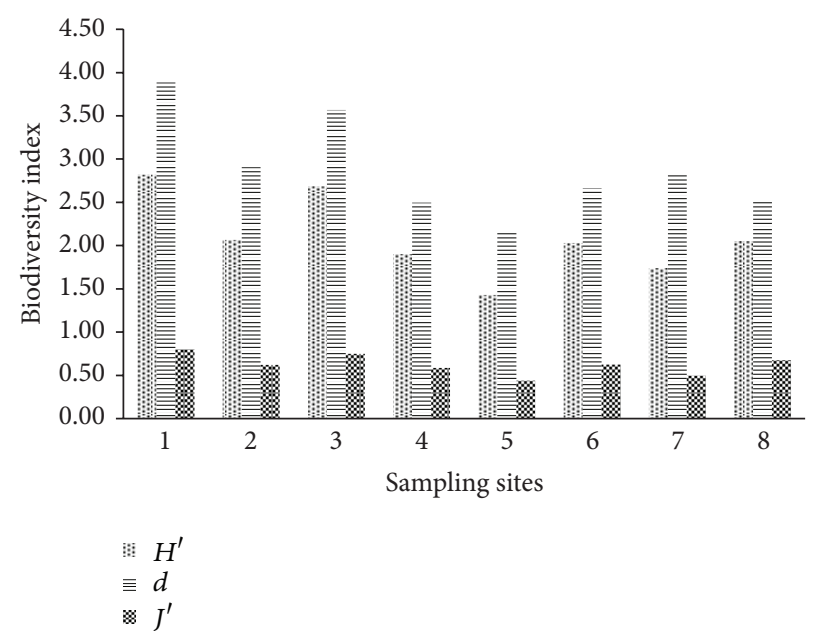

(a)

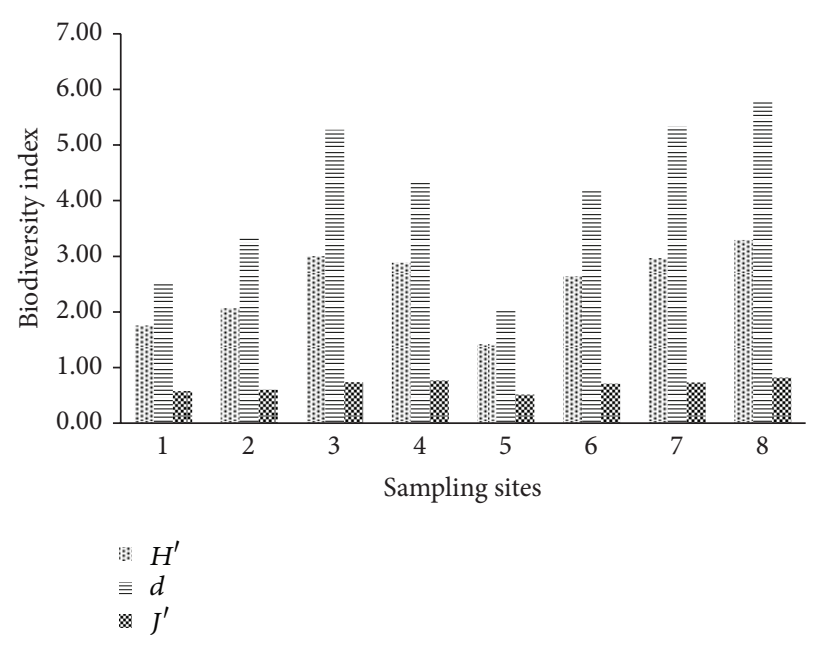

(b)

FIGURE 3: Biodiversity index of the phytoplankton in different sampling sites in Baiyangdian Lake in spring (a) and summer (b).

belongs to the Chlorophyta phylum with the occurrence frequency of $100 \%$. The second dominant species are Leptolyngbya valderiana Anagn. and Nephrocytium agardhianum Nageli. which belongs to the Cyanophyta and Chlorophyta phyla with occurrence frequency of $70 \%$ and $88 \%$, respectively.

Figure 3 shows the biodiversity index of the phytoplankton in Baiyangdian Lake sampling sites in spring (a) and summer (b). As shown in Figure 3(a), the Shannon-Weiner index of phytoplankton was $1.43 \sim 2.82$ with an average of 2.09 , and the species richness index of phytoplankton was 2.15 3.89 with an average of 2.88. The Shannon-Weiner index for Site 5 was the lowest (1.43), and the richness index is 2.15; the Shannon-Weiner index for Site 1 was the highest (2.82), and the richness index is 3.89. It is obvious that the space distribution tendency of Shannon-Weiner index and species richness index was consistent. The uniformity index was $0.44 \sim 0.80$ with an average of 0.62 . In summer, the Shannon-Weiner index of phytoplankton was 1.42 3.29 with an average of 2.50, and the species richness index of phytoplankton was 2.05 5.78 with an average of 4.11 (Figure 3(b)). The Shannon-Weiner index for Site 5 was the lowest (1.42), and the richness index is 2.05; the ShannonWeiner index for Site 8 was the highest (3.29), and the richness index is 5.78. The space distribution tendency of ShannonWeiner index and species richness index was consistent. The uniformity index of phytoplankton was $0.51 \sim 0.82$ with an average of 0.68. According to this, in Baiyangdian Lake, there were more species of phytoplankton in summer than in spring but there was no dominant group; Chlorophyta and Cyanophyta dominated the community in both spring and summer. In sampling sites close to residential area, fish culturing cages, livestock, and poultry farms which were under great influence of human activities, there were more varieties of phytoplankton; while in sampling sites, which were situated in lake outlets and in standing water, there were fewer varieties of phytoplankton. This is consistent with the

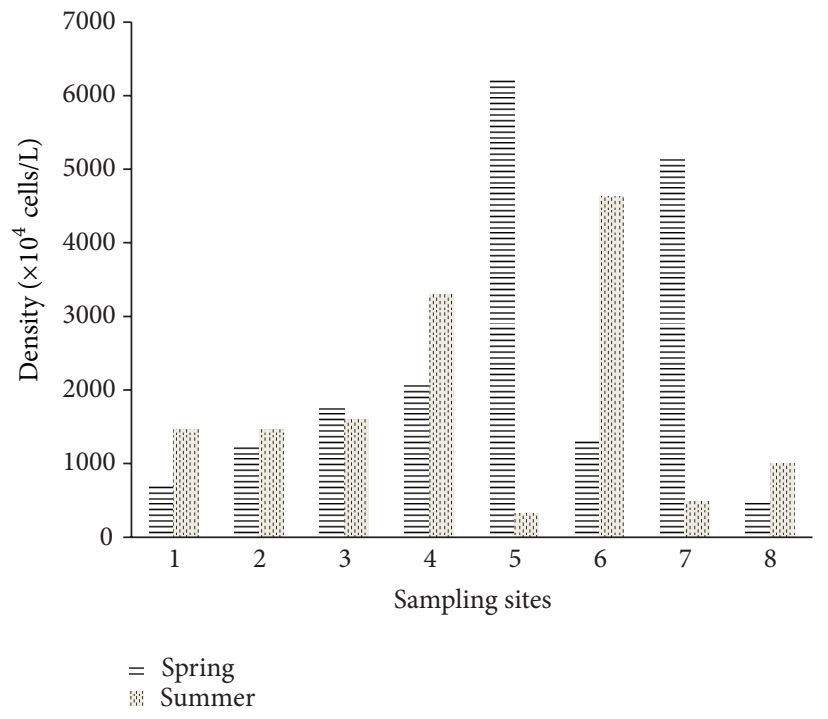

Figure 4: Comparison of phytoplankton density in different sampling sites in Baiyangdian Lake in spring and summer.

results in previous studies of phytoplankton in Baiyangdian Lake [17].

3.2. Phytoplankton Density. The number of phytoplankton in Baiyangdian Lake varied greatly between spring and summer. In spring, the density of phytoplankton varied from $496 \times 10^{4}$ to $6256 \times 10^{4} \mathrm{cells} / \mathrm{L}$ with an average of $2384 \times 10^{4} \mathrm{cells} / \mathrm{L}$; the density varied greatly between different sampling sites: the density of phytoplankton cells in Sites 5 and 7 was high, while the density of Sites 1 and 8 was low. In summer, the density of phytoplankton varied from $318 \times 10^{4}$ to $4630 \times 10^{4}$ cells $/ \mathrm{L}$ with an average of $1785 \times 10^{4}$ cells/L (Figure 4); the density varied greatly between different sampling sites: the density of phytoplankton cells in Sites 4 and 6 was high, while the 
TABLE 1: Variations of phytoplankton density and dominant species.

\begin{tabular}{ccccccccrr}
\hline Year & $\begin{array}{c}\text { Number } \\
(\text { species })\end{array}$ & $\begin{array}{c}\text { Density } \\
\left(\times 10^{4} \text { cells/L) }\right.\end{array}$ & $\begin{array}{c}\text { Dominant } \\
\text { species }\end{array}$ & $\begin{array}{c}\text { Number } \\
(\text { species })\end{array}$ & Percentage \% & $\begin{array}{c}\text { Dominant } \\
\text { species }\end{array}$ & $\begin{array}{c}\text { Number } \\
\text { (species) }\end{array}$ & Percentage \% Data resource \\
\hline 2005 & 152 & 664.4 & Chlorophyta & 80 & 52.6 & Cyanophyta & 28 & 18.4 & {$[20]$} \\
2006 & 155 & 518.2 & Chlorophyta & 81 & 52.3 & Cyanophyta & 29 & 18.7 & {$[20]$} \\
2009 & 133 & 2084.6 & Chlorophyta & 65 & 48.9 & Cyanophyta & 22 & 16.5 & This study \\
\hline
\end{tabular}

TABLE 2: Correlation analysis between phytoplankton density and environmental factors of Baiyangdian Lake in spring.

\begin{tabular}{|c|c|c|c|c|c|c|c|c|c|c|}
\hline & $\mathrm{T}$ & $\mathrm{DO}$ & $\mathrm{COD}$ & $\mathrm{COD}_{\mathrm{Mn}}$ & $\mathrm{pH}$ & TN & $\mathrm{TP}$ & Chla & SD & Density \\
\hline $\mathrm{T}$ & 1 & & & & & & & & & \\
\hline DO & 0.024 & 1 & & & & & & & & \\
\hline COD & $0.760^{*}$ & -0.454 & 1 & & & & & & & \\
\hline $\mathrm{COD}_{\mathrm{Mn}}$ & $0.867^{* *}$ & -0.285 & $0.948^{* *}$ & 1 & & & & & & \\
\hline $\mathrm{pH}$ & 0.458 & $0.753^{*}$ & 0.022 & 0.108 & 1 & & & & & \\
\hline $\mathrm{TN}$ & 0.274 & -0.476 & 0.566 & 0.602 & -0.249 & 1 & & & & \\
\hline $\mathrm{TP}$ & 0.286 & -0.428 & 0.550 & 0.600 & -0.207 & $0.998^{* *}$ & 1 & & & \\
\hline Chla & 0.627 & 0.513 & 0.442 & 0.492 & $0.851^{* *}$ & 0.057 & 0.089 & 1 & & \\
\hline $\mathrm{SD}$ & -0.069 & -0.212 & -0.264 & -0.220 & -0.439 & -0.382 & -0.399 & -0.687 & 1 & \\
\hline Density & 0.644 & -0.132 & 0.651 & 0.543 & 0.308 & -0.223 & -0.241 & 0.512 & -0.067 & 1 \\
\hline
\end{tabular}

* Significant correlation at the level of $P<0.05$; ${ }^{* *}$ significant correlation at the level of $P<0.01$.

density of Sites 5 and 7 was low. Generally speaking, the density of phytoplankton and dominant species can indicate the eutrophication degree of certain water. As species of high pollution tolerant, if Cyanophyta increases sharply and finally becomes the dominant species, it indicates that the water is eutrophic, that is to say, the higher the density of Cyanophyta cells is, the more serious the eutrophication is [18]. According to this survey, cyanophyta and Chlorophyta became dominant in the phytoplankton community, that may be caused by the increased organic matters after organic matters in industrial wastewater and domestic sewage came into Baiyangdian Lake [19] and resulted in the increase of varieties and number of phytoplankton, especially these species with high pollution tolerance.

To get a general understanding of the change of phytoplankton community in Baiyangdian Lake, data of the three times surveys of phytoplankton since 2005 were compared (Table 1), and dynamic variations of phytoplankton in Baiyangdian Lake in recent years were analyzed from the aspects of species composition, density, and dominant species. The data of the years 2005 and 2006 were averages from the 8 sampling sites in Baiyangdian Lake in spring and summer, and the data of the year 2009 were averages from the current survey in 8 sampling sites in Baiyangdian Lake in spring and summer. The survey methods were the same.

Table 1 shows the variations of phytoplankton density and dominant species in Baiyangdian Lake in recent years. Taking the year 2005 as the reference point, the average phytoplankton density decreased 0.22 times in 2006, whereas the average phytoplankton density increased 2.41 times in 2009. In the three surveys, Chlorophyta and Cyanophyta were the mainly dominant species. The annual variations tendency of different algae phylums were different; the phytoplankton variety number tended to decrease, while the phytoplankton density tended to increase. In the current survey, the phytoplankton density increased observably, because the nutrient load in Baiyangdian Lake changed; when sampling, algae were growing and blooming, and as the temperature became higher and the light became stronger, the water environment became more favorable for the growth of phytoplankton which abundance increased as a result. Generally speaking, in mesotrophic lakes, Pyrrophyta, Cryptophyta, and Bacillariophyta are the dominant species, and in eutrophic lakes, Chlorophyta and Cyanophyta are the dominant species [21]. From this, a conclusion can be drawn that Chlorella sp. and Microcystis incerta Lemm. which belong to the Chlorophyta and Cyanophyta phyla, respectively, are becoming the dominant species, indicating that Baiyangdian Lake had become eutrophic and organic matters tended to increase year by year.

3.3. Relationship between Phytoplankton and Environmental Factors. Nine environment factors, chemical oxygen demand (COD), potassium permanganate index $\left(\mathrm{COD}_{\mathrm{Mn}}\right)$, total nitrogen (TN), total phosphorus (TP), chlorophyll a (Chla), pH, dissolved oxygen (DO), secchi depth (SD), and temperature, were selected in the eight sampling sites. The Pearson correlation analysis showed that no significant correlation was observed between phytoplankton cell density and environmental factors in spring (Table 2). In summer (Table 3), phytoplankton cell density was greatly influenced by DO $(r=0.813, P=0.014)$, Chla $(r=0.818, P=$ $0.024)$, and TP $(r=0.833, P=0.010)$, and there was a positive correlation between them. According to this, the best environment factor combination could not be identified which influenced the space distribution of phytoplankton in Baiyangdian Lake in summer, and DO, Chla, and TP 
TABLE 3: Correlation analysis between phytoplankton density and environmental variables of Baiyangdian Lake in summer.

\begin{tabular}{|c|c|c|c|c|c|c|c|c|c|c|}
\hline & $\mathrm{T}$ & $\mathrm{DO}$ & COD & $\mathrm{COD}_{\mathrm{Mn}}$ & $\mathrm{pH}$ & $\mathrm{TN}$ & $\mathrm{TP}$ & Chla & SD & Density \\
\hline $\mathrm{T}$ & 1 & & & & & & & & & \\
\hline DO & -0.321 & 1 & & & & & & & & \\
\hline COD & -0.617 & 0.295 & 1 & & & & & & & \\
\hline $\mathrm{COD}_{\mathrm{Mn}}$ & 0.087 & 0.518 & 0.100 & 1 & & & & & & \\
\hline $\mathrm{pH}$ & 0.241 & 0.329 & -0.070 & 0.484 & 1 & & & & & \\
\hline $\mathrm{TN}$ & $-0.814^{*}$ & 0.472 & 0.555 & 0.455 & 0.107 & 1 & & & & \\
\hline $\mathrm{TP}$ & -0.522 & $0.930^{* *}$ & 0.424 & 0.423 & 0.267 & 0.645 & 1 & & & \\
\hline Chla & -0.454 & $0.930^{* *}$ & 0.337 & 0.669 & 0.313 & 0.687 & $0.982^{* *}$ & 1 & & \\
\hline SD & 0.339 & -0.089 & -0.342 & -0.556 & -0.364 & $-0.724^{*}$ & -0.318 & -0.622 & 1 & \\
\hline Density & -0.245 & $0.813^{*}$ & -0.011 & 0.498 & 0.630 & 0.505 & $0.833^{*}$ & $0.818^{*}$ & -0.357 & 1 \\
\hline
\end{tabular}

${ }^{*}$ Significant correlation at the level of $P<0.05 ;{ }^{* *}$ significant correlation at the level of $P<0.01$.

were probably the important factors which influenced the space distribution of phytoplankton in Baiyangdian Lake in summer. The main reason for this is that summer is usually the time for algal bloom occurrence in eutrophic lakes. In the sampling Sites 3 and 7, because breeding industry and crop farming were flourishing, the concentration of nutrients in water was high, while algae bloom, DO, and the phytoplankton cell density were low. In the sampling Sites 5 and 1, because the water was open and far from pollution source, the water quality was good and the phytoplankton cell density was low.

Phytoplankton cell density varied greatly from season to season mainly due to the water temperature. Environment factors have different influences on the community structure and species number of phytoplankton in different lakes: SONG Xiao-lan's study on the community structure of phytoplankton in Taihu Lake and Wulihe River found that wind wave and eutrophication degree were the restrictive conditions for growth of phytoplankton species [22]. Jeppesen pointed out that in lakes the density of filtering-feeding fish was a factor closely correlated with the variety and number of phytoplankton [23]. However, other unknown physical, chemical, and biological factors can probably directly or indirectly influence the number of phytoplankton in a certain way, because the growth of phytoplankton is also related to many other factors (e.g., water stability, climate, lake area, lake depth, spatial distribution of organic matter and heavy metals in wetland soils, the community structure, and density of hydrophyte) [24-35]. Therefore, it is difficult to do "dose-effect analysis" of the interaction between the number of phytoplankton and the abovementioned factors. It is suggested that in the future research, more efforts should be made to study lake type, climate characteristics, and surrounding environment, and simulated experiments should be also included to the impact factors on variation of phytoplankton number.

3.4. Eutrophication Degree Assessment. Generally, the excessive growth of phytoplankton is the characterization of eutrophication. Chla, SD, and dominant species are usually regarded as the most important indicators for the assessment of eutrophication degree. In this paper, the index of TSIM
TABLE 4: Assessment results of trophic status index of Baiyangdian Lake in 2009.

\begin{tabular}{lcc}
\hline Item & TSIM & Trophic status \\
\hline TP & 77.00 & Eutrophic \\
Chla & 47.6 & Mesotrophic \\
SD & 69.24 & Eutrophic \\
\hline
\end{tabular}

and the dominant genus assessment were used to assess the trophic status of Baiyangdian Lake [36]. The index of Carlson nutritional status (TSIM) can elaborately describe the change of water trophic status and can also improve water quality monitoring and assessment. The method is to grade the lake trophic status with numbers from 0 to 100 according to the relation between SD, Chla, and TP. Index under 30 indicates oligotrophic water, index from 30 to 50 indicates mesotrophic water, and index from 50 to 100 indicates eutrophic water. Under the same trophic status, the higher the index is, the more serious the eutrophication is. According to this assessment result (Table 4), water in Baiyangdian Lake is mesotrophic and eutrophicconsider the following:

$$
\begin{gathered}
\text { TSIM }(\text { Chl } a)=10 \times\left(2.46+\frac{\ln C h l a}{\ln 2.5}\right), \\
\operatorname{TSIM}(\mathrm{TP})=10 \times\left[2.46+\frac{(6.71+1.15 \times \operatorname{lnTP})}{\ln 2.5}\right], \\
\operatorname{TSIM}(\mathrm{SD})=10 \times\left[2.46+\frac{(3.69-1.53 \times \operatorname{lnSD})}{\ln 2.5}\right] .
\end{gathered}
$$

In this formula, Chl $a$ is the content of chlorophyll a; SD is secchi depth; TP is total Phosphorus.

According to the dominant genus assessment, dominant phytoplankton genus observed in this survey included not only indicator species for eutrophication, such as Chlorella sp., but also indicator species for serious eutrophication, such as Microcystis incerta Lemm. and Chroomonas acuta Uterm. with indicator species for eutrophication as the dominant species. According to these two methods, Baiyangdian Lake was at eutrophic status, which was consistent with SHEN Hui-tao's [19] research conclusion in the year 2006, in which 
the majority of Baiyangdian Lake was at eutrophic status and the eutrophication tended to be aggravated.

\section{Conclusions}

Eutrophication degree assessing methods can be broadly divided into two types: biological monitoring method and comprehensive indicators method. This study was carried out by combing the dominant genus assessment and the index of TSIM to assess comprehensively the eutrophication degree of Baiyangdian Lake. Generally, the species composition of phytoplankton in Baiyangdian Lake changed significantly, and the density tended to increase compared to the results of comprehensive ecological surveys in recent years. Baiyangdian Lake tended to become seriously eutrophic now. It is necessary to use different approaches to assess eutrophication due to the limitation of these approaches. Moreover, both methods for eutrophication degree assessment in this study are convenient and applicable, and it can be used to assess the impacts of organic matter pollution in other similar cases across China. The finding of this study provides necessary theoretical and data support for the control of eutrophication in Baiyangdian Lake. However, further studies are still needed on the species composition, quantity characteristics, and distribution characteristics of the phytoplankton in Baiyangdian Lake for eutrophication prevention and control and for the conservation of biodiversity.

\section{References}

[1] W. Rodhe, "Crystallization of eutrophication concepts in North Europe," in Eutrophication, Causes, Consequences, Correctives, pp. 50-64, National Academy of Sciences, 1969.

[2] ILEC/Lake Biwa Research Institute, 1988-1993 Survey of the State of the World's Lakes, vol. 1-4, International Lake Environment Committee and United Nations Environment Programme, 1993.

[3] Z. X. Liu, G. P. Wu, and J. F. Tu, "Eutrophication status and governance of major lakes in Japan," Express Water Resources and Hydropower Information, vol. 28, no. 11, pp. 5-13, 2007 (Chinese).

[4] B. Q. Qin, "Approaches to mechanisms and control of eutrophication of shallow lakes in the middle and lower reaches of the Yangze River," Journal of Sciences, vol. 14, no. 3, pp. 193-202, 2002 (Chinese).

[5] M. Shao, X. Y. Tang, Y. H. Zhang, and W. Li, "City clusters in China: air and surface water pollution," Frontiers in Ecology and the Environment, vol. 4, no. 7, pp. 353-361, 2006.

[6] S. V. Mize and D. K. Demcheck, "Water quality and phytoplankton communities in Lake Pontchartrain during and after the Bonnet Carré Spillway opening, April to October 2008, in Louisiana, USA," Geo-Marine Letters, vol. 29, no. 6, pp. 431-440, 2009.

[7] H. Lei, Y. Q. Liang, A. M. Zhu et al., "Phytoplankton and water quality in the Tongzhuang River of Three Gorges Reservoir," Journal of Lake Science, vol. 22, no. 2, pp. 195-200, 2010 (Chinese).

[8] P. Y. Guo, Y. Z. Lin, and Y. X. Li, "Study on phytoplankton and evaluation of water quality in Dongping Lake," Transaction of Oceanology and Limnology, no. 4, pp. 37-42, 1997 (Chinese).
[9] L. Ren, Z. C. Dong, and S. H. Li, "Research on phytoplankton and water eutrophication of Xuanwu Lake," Water Resources and Power, vol. 26, no. 4, pp. 31-32, 2008 (Chinese).

[10] M. Cao, Q. H. Cai, R. Q. Liu, X. D. Qu, and L. Ye, "Comparative research on physicohemical factors between Xiangxi Bay and the front region of Three Gorges Reservoir," Acta Hydrobiologica Sinica, vol. 30, no. 1, pp. 20-25, 2006 (Chinese).

[11] H. F. Gao, J. H. Bai, R. Xiao, P. P. Liu, W. Jiang, and J. J. Wang, "Levels, sources and risk assessment of trace elements in wetland soils of a typical shallow freshwater lake, China," Stochastic Environmental Research and Risk Assessment, vol. 27, no. 1, pp. 275-284, 2013.

[12] X. Liu, M. Xu, Z. Yang et al., "Sources and risk of polycyclic aromatic hydrocarbons in Baiyangdian Lake, North China," Journal of Environmental Science and Health A, vol. 45, no. 4, pp. 413-420, 2010.

[13] C. Y. Chen, P. C. Pickhardt, M. Q. Xu, and C. L. Folt, "Mercury and arsenic bioaccumulation and eutrophication in Baiyangdian Lake, China," Water, Air, and Soil Pollution, vol. 190, no. 1-4, pp. 115-127, 2008.

[14] C. L. Liu, G. D. Xie, and H. Q. Huang, "Shrinking and drying up of Baiyangdian Lake wetland: a natural or human cause?" Chinese Geographical Science, vol. 16, no. 4, pp. 314-319, 2006.

[15] W. M. Chen, X. F. Huang, and W. P. Zhou, Lake Ecosystem Observation Methods, China Environmental Science Press, 2005.

[16] K. R. Clarke and R. M. Warwick, "Change in marine communities: an approach to statistical analysis and interpretation," Natural Environment Research Council, pp. 24-36, 1994.

[17] H. T. Shen and C. Q. Liu, "Canonical correspondence analysis of phytoplankton community and its environmental factors in the Lake Baiyangdian," Journal of Lake Science, vol. 20, no. 1, pp. 773-779, 2008 (Chinese).

[18] Z. H. Wang, Q. Q. Lin, R. Hu, C. L. Fan, and B. P. Han, "Pollution by blue-green algae (Cyanophyta) in reservoirs of Guangdong Province and water quality evaluation," Journal of Tropical and Subtropical Botany, vol. 12, no. 2, pp. 117-123, 2004 (Chinese).

[19] Y. H. Li, B. S. Cui, and Z. F. Yang, "Influence of hydrological characteristic change of Baiyangdian on the ecological environment in wetland," Journal of Natural Resources, vol. 19, no. 1, pp. 62-68, 2004 (Chinese).

[20] H. T. Shen, The Ecological Study of Phytoplankton Community in the Baiyangdian Lake, Hebei University, 2007.

[21] Q. Q. Pang and B. Y. Li, "Eutrophication degree assessment of Dongping Lake, China," Water Resources Protection, vol. 19, no. 5, pp. 42-44, 2003 (Chinese).

[22] X. L. Song, Z. W. Liu, H. K. Pan, G. J. Yang, and Y. W. Chen, "Phytoplankton community structure in Meiliang Bay and Lake Wuli of Lake Taihu," Journal of Lake Science, vol. 19, no. 6, pp. 643-651, 2007 (Chinese).

[23] E. Jeppesen, M. Søndergaard, O. Sortkjoær, E. Mortensen, and P. Kristensen, "Interactions between phytoplankton, zooplankton and fish in a shallow, hypertrophic lake: a study of phytoplankton collapses in Lake Søbygård, Denmark," Hydrobiologia, vol. 191, no. 1, pp. 149-164, 1990.

[24] M. X. Zhao and B. P. Han, "Analysis of factors affecting cyanobacteria bloom in a tropical reservoir (Tangxi Reservoir, China)," Acta Ecologica Sinica, vol. 25, no. 7, pp. 1554-1561, 2005 (Chinese).

[25] G. B. Arhonditsis, M. Winder, M. T. Brett, and D. E. Schindler, "Patterns and mechanisms of phytoplankton variability in Lake 
Washington (USA)," Water Research, vol. 38, no. 18, pp. 40134027, 2004.

[26] U. Gaedke, "The size distribution of plankton biomass in a large lake and its seasonal variability," Limnology and Oceanography, vol. 37, no. 6, pp. 1202-1220, 1992.

[27] L. B. Huang, J. H. Bai, H. F. Gao, R. Xiao, P. P. Liu, and B. Chen, "Soil organic carbon content and storage of raised field wetlands in different functional zones of a typical shallow freshwater lake, China," Soil Research, vol. 50, no. 8, pp. 664-671, 2012.

[28] L. B. Huang, J. H. Bai, R. Xiao, H. F. Gao, and P. P. Liu, "Spatial distribution of $\mathrm{Fe}, \mathrm{Cu}, \mathrm{Mn}$ in the surface water system and their effects on wetland vegetation in the Pearl River Estuary of China," Clean-Soil, Air, Water, vol. 40, no. 10, pp. 1085-1092, 2012.

[29] E. H. Na and S. S. Park, "A hydrodynamic and water quality modeling study of spatial and temporal patterns of phytoplankton growth in a stratified lake with buoyant incoming flow," Ecological Modelling, vol. 199, no. 3, pp. 298-314, 2006.

[30] J. H. Bai, R. Xiao, K. J. Zhang, and H. F. Gao, "Arsenic and heavy metal pollution in wetland soils from tidal freshwater and salt marshes before and after the flow-sediment regulation regime in the Yellow River Delta, China," Journal of Hydrology, vol. 450451, pp. 244-253, 2012.

[31] J. H. Bai, B. S. Cui, B. Chen et al., "Spatial distribution and ecological risk assessment of heavy metals in surface sediments from a typical plateau lake wetland, China," Ecological Modelling, vol. 222, no. 2, pp. 301-306, 2011.

[32] F. X. Kong and G. Gao, "Hypothesis on cyanobacteria bloomforming mechanism in large shallow eutrophic lakes," Acta Ecologica Sinica, vol. 25, no. 3, pp. 589-595, 2005 (Chinese).

[33] C. G. Liu, X. C. Jin, L. Sun et al., “Temporal and spatial distribution of nutrients and algae in urban small artificial lake enclosures," Acta Scientiae Circumstantiae, vol. 24, no. 6, pp. 1039-1045, 2004 (Chinese).

[34] J. H. Bai, Q. G. Wang, K. J. Zhang et al., "Trace element contaminations of roadside soils from two cultivated wetlands after abandonment in a typical plateau lakeshore, China," Stochastic Environmental Research and Risk Assessment, vol. 25, no. 1, pp. 91-97, 2011.

[35] Q. G. Wang, S. B. Li, P. Jia, C. C. Qi, and F. Dang, "A review of surface water quality models," The Scientific World Journal, vol. 2013, Article ID 231768, 7 pages, 2013.

[36] Z. S. Zhang, "Macrophyte-phytoplankton relationship and lake trophic status," Journal of Lake Science, vol. 10, no. 4, pp. 83-86, 1998 (Chinese). 

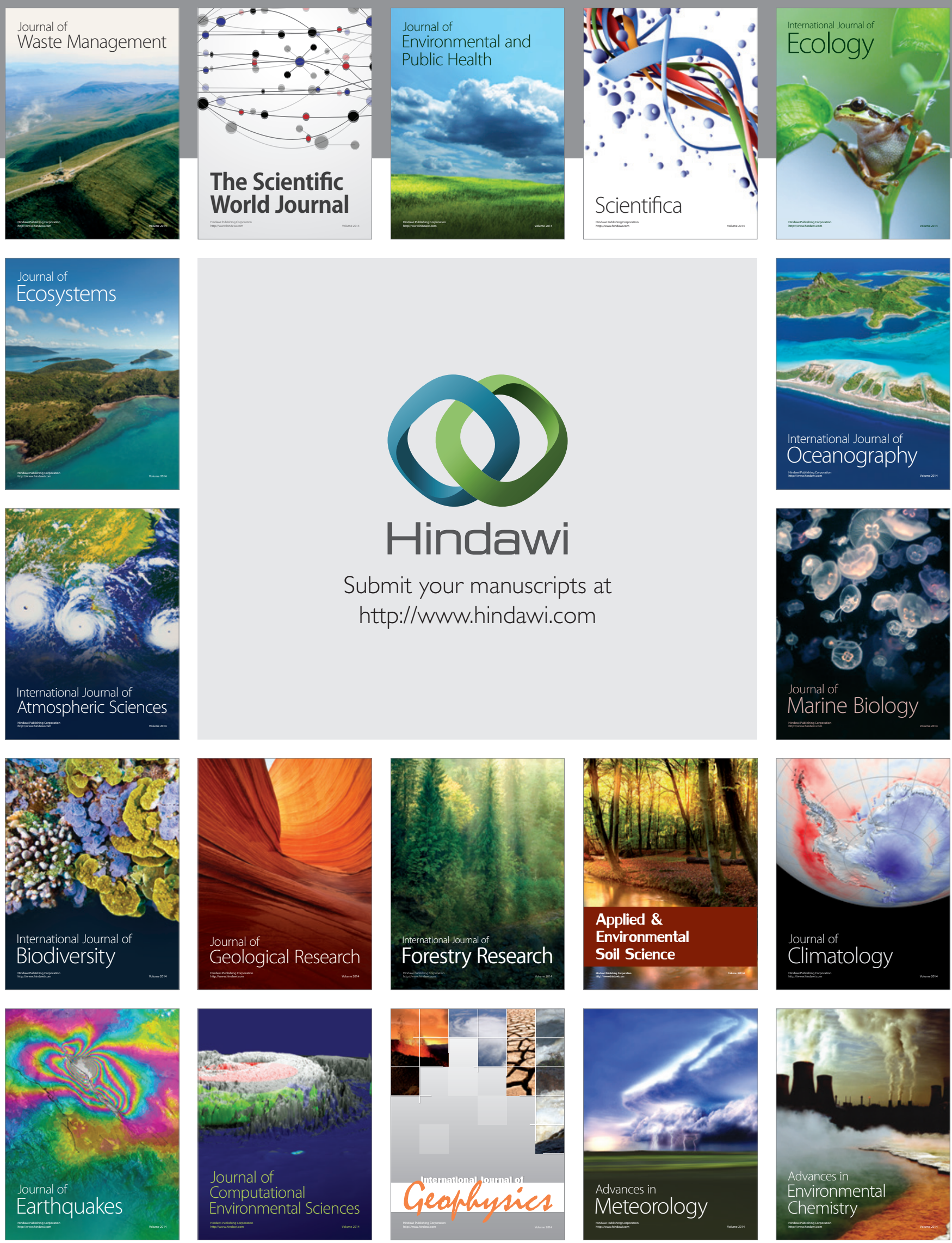